\title{
Influence Of Policy Framework On Budgeting For Science Instructional Resources In Kenyan Secondary Schools
}

\author{
Paul Amollo Odundo \\ Department of Educational Communication and Technology \\ University of Nairobi, Kenya \\ Charles Richard Oyier \\ Department of Educational Communication and Technology \\ University of Nairobi, Kenya
}

\begin{abstract}
Instructional resources are educational inputs that aid teaching and learning process. Planning for instructional resources demands that money be set aside and budgeted for to assure their availability and adequacy. Schools financial management policy framework guides budgeting process in instructional management and the extent of involvement of science teachers.. This was a descriptive survey which targeted science teachers and principals in 6 national secondary schools, 60 county secondary schools and 66 private secondary schools in Nairobi County. Information was obtained through questionnaires and interview from a sample of 108 selected using mixture of stratified and simple random sampling techniques. Findings indicated that secondary schools in Nairobi County have a financial management policy (mean of 3.82) and that this has objectives that inform budgetary allocation for instructional resources for sciences (mean of 3.47), guide sources of funds for budgetary allocations for instructional management (Mean of 3.35), provide for standardized procedures in sourcing for science instructional resources (mean of 3.41) and has accountability provisions (Mean of 3.57). Recommendations from the study aimed at the need to institute appropriate regulatory mechanisms to enhance instructional management in terms of budgetary allocation and utilization and further research on the role science teachers in financial decision making as far as instructional management is concerned.
\end{abstract}

Key words: Budgeting Process, Policy Framework, Science Subjects, Instructional Resources, , budgeting guidelines, budgetary priorities, sources of funds and financial accountability

\section{INTRODUCTION}

Quality instruction can only be achieved when instructional resources are planned for and made available. Instructional resources are educational inputs that are of vital importance in ensuring quality of education. Hammond (2007) asserted that in order to raise the quality of education, its efficiency and productivity, proper planning for learning materials is essential. In support of this argument, Jebet and Naserian (2003) noted that effective teaching of science subjects requires adequate and appropriate instructional resources. Planning for instructional resources demands that money be set aside and budgeted for to assure their availability and adequacy. Agreeing with this Uya (2004), noted that budgeting for instructional resources is no doubt an essential part of instructional planning without which effective learning cannot take place,. An interaction between policy and practice in budgeting process assures provision and availability of science instructional resources in schools. Policy framework guides budgeting process in instructional management and the extent of involvement of stakeholders including science teachers. This interaction between policy and practice determines quality instruction in teaching and learning science subject in secondary schools. Further, Etindi (2001) noted that quality instruction in schools depends on leadership and governance of the institution, which in turn influence budgeting process. An effective budgeting process would 
go a long way in overseeing, directing, conducting, regulating and controlling instructional management in schools. In support of the influence of budgeting process as a factor in quality instruction, Okumbe (2007) argues that for effective teaching and learning of science to take place adequate instructional resources must be available.

\section{Budgeting and Education as a Human Right.}

Budgeting for instructional resources is an aspect of financial management. Secondary schools budgeting process is linked to effective and efficient use of resources towards realization educational goals through quality instructions. In Kenya, national educational policy framework guides provision instructional management through a number of legislations and policy paper ( Chaudhury et al, 2006). Provisions of national education policy are derived from international legal instruments. At secondary school level, these provisions should act as a link to demands of education as human rights with instructional management. Nolan (2011) in an article on Economic and Social Rights, Budgets and the Convention on the Rights of the Child stressed that schools when developing financial management policy should consider national aspirations on education. One way through which national educational aspiration can be realized is through adequate budgetary allocation for science instructional resources. School financial management policy provides guideline in budgeting for instructional resources through influence on budgeting guidelines, budgetary priorities, sources of resources and financial accountability. Du Preez, Grobler, Lock and Shaba (2003) in module on Managing School Finances which is part of Effective Education Management Series asserted that secondary schools need financial policy to enable them organize and manage available funds for quality instructions.

\section{Budgeting for Instructional Recourses and School Financial Management Policy}

Bisschoff and Mestry (2003) in a publication from South Africa on school financial management suggested that for schools to fairly allocate limited resources to several and demanding need, budgeting process should be guided by a financial management policy. However, despite existence of rich literature suggesting the need to arrive at a balance budget to address competing demands, studies have not been done to ascertain if secondary schools have financial management policies. Such a policy should first take into considerations population of students, infrastructure and staffing to enable the institution to achieve its instructional goals. Secondly, it should consider quality science instruction is a pre-requisite towards realization of educational goals in all nations worldwide. Locally, Kenya government recognizes the key role played by science in building innovative human capital required for the transition to much desired knowledge driven economy (Onsomu, 2014). It is expected that financial policy framework from national level would bring uniformity in instructional management in schools in any country and specifically in Kenya if they do exist. However, caution was taken because different leadership styles. Supporting this position, Asiabaka (2008) from Nigeria confirmed that management disparities exist in provision of instructional resources and their utilization in schools across Sub-Saharan Africa, Therefore it was necessary to establish if secondary schools have financial management policies to influence budgetary allocation for science instructional resources in Nairobi County in Kenya.

\section{Budgeting for Instructional Management and Secondary Schools Leadership Styles}

Secondary schools leadership styles would resulted in disparities in instructional management, despite fact that education philosophy emphasizes the inculcations of a high quality science instructions. For this reason Asiabaka (2008) in a study on effective management of schools Nigerian government's failure to put in place a policy framework on minimum standards in budgetary allocations for science instructional resources. Studies have linked secondary 
schools principals' leadership styles to performance in general, but this study took a different directions by looking at its influence on science instruction through financial management policy. It was necessary to build on work done by others scholars on leadership of secondary schools and narrow down to its influence on institutional financial management. Leadership influence on school financial management will have a direct influence on budgetary allocations for science instructional resources and indirectly learning outcomes. Robinson, Lloyd and Rowe (2008) in a study on the impact of leadership on school outcomes in New Zealand through meta-analysis indicated that the average effect of instructional leadership on learning outcomes was three to four times that of transformational leadership. Learning outcomes are dependent on availability and utilization instructional resources, which in turn are influence by school budgeting process. Supporting this position Okumbe (2007) asserted that quality instructions can only be achieved when adequate instructional resources can only be availed through budgetary allocation. The influence of leadership on learning outcomes can only be traced through school financial policy which guides budgetary allocations for instructional resources. In their findings Robinson, Lloyd and Rowe (2008) didn't take consideration specific effect of budgetary allocations on learning outcomes through utilization of instructional resources.

Ideally, financial management policy framework is intended to provide school leadership with a basis for ensuring adequate instructional resources for learning science subjects. Supporting this position, Du Preez et al (2003) asserted that school financial policy is important for instructional management through determination of budgetary allocations. In several countries including those in Sub-Saharan Africa Ministries of Education provides policy guidelines on financial management for secondary schools. These are expected to streamline instructional management towards realization of national education goals. According to Motsamai, Jacobs and Corene (2011), despite the efforts of the Lesotho Ministry of Education to enhance principals' performance and the existence of guidelines financial management capacity is a concern in secondary schools. This is an indication of capacity gap in regard to implementation of the policy which can be attributed to leadership style. This study focused on financial leadership by considering existence of a policy framework and its influence on budgeting guidelines, budgetary priorities, sources of resources and accountability in secondary schools in Nairobi County, Kenya.

\section{School Financial Management Policy and Budgeting Guidelines}

Financial management policy provides for economic planning and utilization of school funds for realization of educational goals. In Nigeria, Asiabaka (2008) noted the government's failure to put in place a policy framework on minimum standards in relation to schools facilities which resulted in disparities in their acquisition. Likewise in Lesotho, Motsamai et al (2011) noted a discrepancy between the policy and school financial theory in secondary schools. In South Africa Joubert and Bray (2007) in an article on public schools governance suggested that institutional financial policy should ensures accountable and prudence in instructional management. In Kenya, Wagithunu et al (2014) acknowledged existence of guidelines on the vote heads and allocation of funds in secondary schools. Ideally, secondary schools financial management policy links transformational and instructional leadership. This linkage would be through guiding budgeting as a framework for overseeing, directing, conducting, regulating and controlling in instructional management in schools. Budgeting guidelines as noted by Ankomah (2005) are intended to provide school leadership with a basis for ensuring availability of adequate instructional resources. Therefore it was necessary to establish existence of school financial management policy in secondary school as a factor influencing budgetary allocation for instructional resources. Further, it was necessary to establish if Nairobi County secondary schools' financial policies have set objectives that inform budgetary allocations for the instructional resources for science subjects. 


\section{School Financial Management Policy and Resourcing Instructional Resources}

Kenya's education is financed from various sources, depending on the types of the educational Institutions. According to Otieno and Colclough (2009), public secondary schools are mainly financed by the government out of funds voted by parliament each year and fees parents pay. Apart from paying teachers in public schools the government through FSE policy meets fees of Kshs. 10,265 per student in secondary school (Obunya, 2008). Out of Kshs. 10,265 paid by government per student Kshs: 3600 is for tuition and should cater for science instructional resources. Schools can also finance budgetary allocations for instructional resources from fees paid by parents, funds from income generating projects, contributions or donations by private sources and special grants from government (KIPPRA, 2007). The fact that secondary schools rely on different fund sources leads to variation on adequacy and availability of instructional resources. Lawrence and Orodho (2014) established that there was skewed distribution of teaching and learning resources among secondary schools in Nakuru District, Kenya. This is an indication that some schools are well equipped as far as adequacy of instructional resources and this would influence learning outcomes in sciences. It also suggest that some schools mobilize resources to supplement government funding and fees to boost instructional resources demands. In supporting this position Obunya (2008) asserted that increased enrollment in secondary schools requires more resources mobilization to supplement government funding and fees paid by parents. This study sought from science teachers if all expected resources including fees, grants and subsidies are considered in budgetary allocation for science instructional resources in Nairobi county secondary schools.

\section{School Financial Management Policy and Standardized Budgeting Procedures}

The mandate of the education sub sector in national development is derived from the Constitution of Kenya, Chapter Four Articles 43, 53, 54, 55, 56, 57, and 59 to facilitate provisions on quality education to the extent compatible with the demands of the Kenya Vision 2030. The Constitution (Republic of Kenya, 2010) sets out the overall guidelines on the management of public resources as provided by various legislations and policy documents. These constitutional provisions are translated into financial management policies to enable institutions and their staff to concentrate their scarce time on instructional priorities. School financial management policy should therefore provide standardized procedures in managing institutional resources. Standardized procedures schools are essential making informed use of most of their resources, demonstrating value for money; exercise proper controls over the significant amounts of public money delegated to them; and allocate resources effectively to meet priorities for realization of educational goals. Among educational goals are effective science instructions for good learning outcomes. However according to Oplatka (2004) principals in developing countries have unique challenges and singles out autocratic leadership style, less open, low degree of change initiation, and lack of instructional leadership functions. There was need to establish existence of standardized procedure $s$ in secondary schools in Nairobi County, Kenya. Therefore this study sought from science teachers if management procedures for sourcing science instructional resources are standardized according to laid down practices.

\section{School Financial Management Policy and Financial Accountability}

Accountability has various activities which includes financial accounting and reporting, accounting controls, procurement controls, physical controls, performance measurement and internal audit. School financial management policy should provide a control system to guide the use of available resources optimally for effective instructional management to produce quality learning outcomes. According to Chetambve and Sakwa (2013) schools' financial management policies should not only ensure that resources adds value towards achieving 
learning outcomes, but also reinforce transparency from budgetary allocation to auditing. However, having accountability provisions in schools is vital a step towards achieving instructional goals and specifically quality learning outcomes in secondary schools. In South Africa, Mestry (2006) reported that teachers have differing perceptions as far as accountability measures in managing funds for the purposes of making instructional resources adequate. Locally, this positions was also held in Transparency International (2010) in an educational sector integrity report and in which it noted that teachers are rarely in the picture as far as financial accountability for effective instructional management was concerned. This is despite provisions of Public Finance Management Act 2012 (Republic of Kenya, 2012) and related legislations enacted pursuant to the provisions of Chapter 12 of the Constitution of Kenya (2010). This study sought from science teachers and secondary principals if institutional financial management policy had provisions for accountability in sourcing of instructional resources in secondary schools in Nairobi county Kenya.

\section{STATEMENT OF THE PROBLEM}

Effective teaching requires adequate and appropriate instructional resources, which can only be availed through planning (Jebet \& Naserian, 2003). An essential part of instructional planning is budgeting which according to Uya (2004) has an influence on effective teachinglearning process. For secondary schools to adequate instructional resources, money need be set aside and budgeted for their acquisition. What guides setting aside funds is a school financial management policy which defines budgetary priorities, sources of resources and accountability in allocation and management of funds as far as science instruction is concerned. Much work has been done on availability, adequacy and utilization of instructional resources and their influence on learning outcome. The gap of knowledge that needs filling is on link between school financial management policy and budgetary allocations for instructional resources. There was a need to examine influence of school financial management policy as guideline for budgeting by providing a basis for availability of instructional resources; a framework for standardized procedures in sourcing and managing instructional resources; its role in outlining possible school funding sources for resourcing instructional management; and its role in providing accountability system that determines how available resources can be used for optimal learning achievements in sciences.

\section{PURPOSE OF THE STUDY}

The purpose of this study was to examine influence of school financial management policy on secondary schools budgeting process and its role in providing accountability system that determines how available resources can be used for optimal learning achievements in sciences.

\section{THEORETICAL FRAMEWORK}

This study employed Education Production Function Theory which considers schools business enterprises. In particular science instructions was considered a production line in which learners are raw materials and instructional resources as some of the inputs among others like teachers and physical facilities are needed to produce learning achievements in science subjects as outputs. As an output learning achievements in sciences according to Walter (2009) is perceived as legitimate to individual and collective good, resulting into growth at national and global arena. Learning achievement in sciences is a pillar national development. Considering instructional resources as input in science instruction Odhong' (2014) asserted that budgetary allocation should be as considered a cornerstone in economic and social development in any nation. 


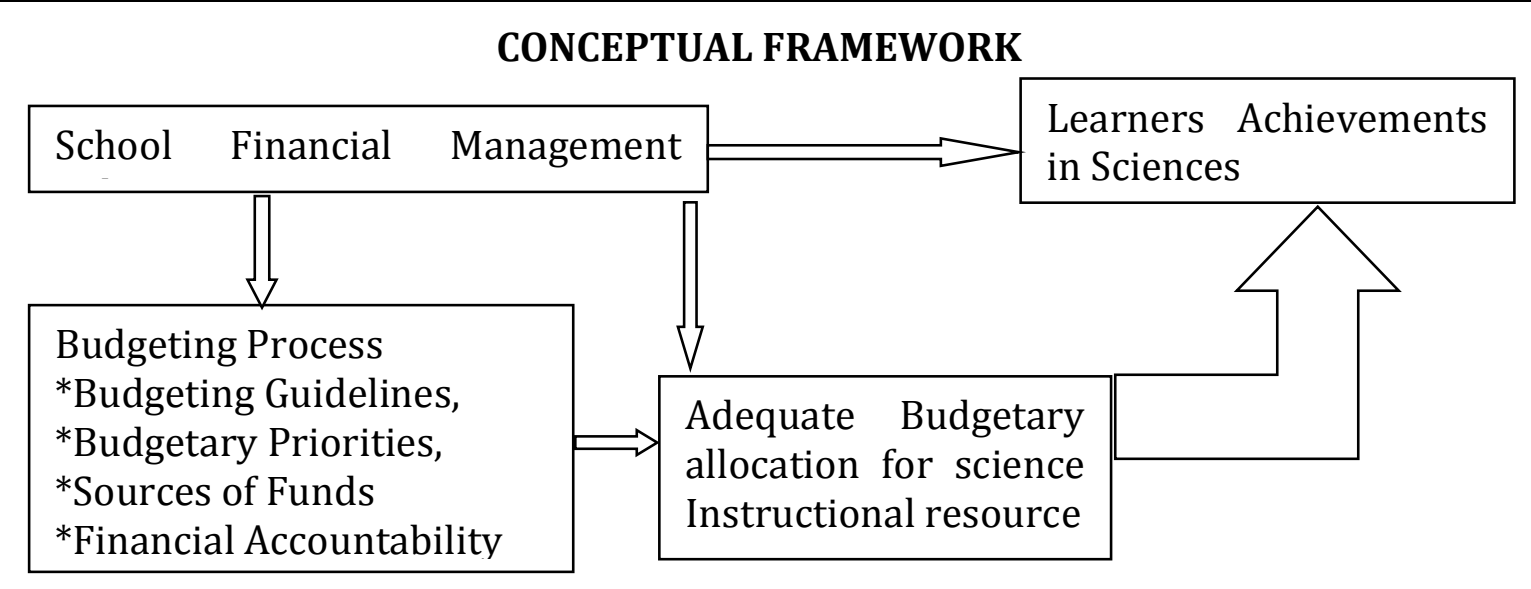

\section{METHODOLOGY}

This research was a descriptive survey which looked into the relationship between policy framework in budgeting process in respect to budgeting guidelines, budgetary priorities, sources of resources and financial accountability in planning for instructional resources for science subjects. The data thus obtained was analyzed using established descriptive statistical procedures. The study targeted science teachers and principals in 6 national secondary schools, 60 county secondary schools and 66 private secondary schools in Nairobi County that have been in existence more than 10 years offering the national 8-4-4 curriculum. Using questionnaires and interview scheduled information was obtained from a sample of 108 selected using stratified random, simple random and purposive sampling technique.

\section{FINDINGS AND DISCUSSION}

There are two categories of secondary schools in Kenya namely public and private. The public secondary schools are funded by the Government or communities and are managed by BOM and Parents Teachers Associations (PTA). The private schools, on the other hand, are established and managed by individuals, private profit making enterprises, foundations and trusts, religious bodies, non-governmental organizations, communities and cooperative societies (Republic of Kenya 2013). In this study the sample was made up of 2 national, 15 county and 16 private schools. Out of 33 sampled secondary schools data was collected from 29 and results presented in Table 1 
Table 1 Schools Background Information

\begin{tabular}{|c|c|c|c|}
\hline \multicolumn{2}{|l|}{ Variable } & \multirow{2}{*}{$\begin{array}{c}\text { Frequency } \\
5\end{array}$} & \multirow{2}{*}{$\begin{array}{c}\text { Percentage } \\
17.20 \%\end{array}$} \\
\hline Number of & $11-20$ & & \\
\hline \multirow[t]{3}{*}{ Teachers } & $21-30$ & 14 & $48.30 \%$ \\
\hline & $31-40$ & 7 & 24.105 \\
\hline & More than 40 & 3 & $10.30 \%$ \\
\hline Number of & $1-2$ & 3 & $10.30 \%$ \\
\hline \multirow[t]{4}{*}{ Streams } & $3-4$ & 17 & $58.60 \%$ \\
\hline & $5-6$ & 6 & $20.70 \%$ \\
\hline & $7-8$ & 2 & $6.90 \%$ \\
\hline & More than 8 & 1 & $3.40 \%$ \\
\hline \multirow[t]{6}{*}{ Type } & Boys Boarding & 3 & $10.30 \%$ \\
\hline & Girls Boarding & 8 & $27.60 \%$ \\
\hline & Boys Day & 3 & $10.30 \%$ \\
\hline & Girls Day & 1 & $3.40 \%$ \\
\hline & Mixed Day & 11 & $37.90 \%$ \\
\hline & Mixed Boarding & 3 & $10.30 \%$ \\
\hline \multirow[t]{3}{*}{ Category } & National & 2 & $6.90 \%$ \\
\hline & County & 15 & $51.72 \%$ \\
\hline & Private & 12 & $41.38 \%$ \\
\hline
\end{tabular}

\section{Category}

From Table 1, 2(6.70\%) of the sampled secondary schools were national secondary schools, $15(51.72 \%)$ were county secondary schools and $12(41.38 \%)$ were private secondary schools. In terms of both financial leadership and instructional management the expectation as far as learning outcomes in science subject is the same in both private and public secondary schools. Secondly, as much as private secondary schools are run as profit making enterprises, section 52 of Basic Education Act No 14, 2013 demands that they establish necessary educational and governance structures including maintaining necessary instructional resources. This provision that requires the private secondary school should to budget for instructional resources and ensure they are utilized to achieve learning outcomes.

\section{Number of Streams in Secondary Schools}

According Oyier, Odundo, Ganira and Wangui (2015) number of streams per class determine complexity of financial and instructional tasks in terms of coordination. Ideally, the number of streams per class in secondary schools determine the level of challenges in financial and instructional management. In this study and as indicated in Table 4.2 secondary schools with 3 or 4 streams were $17(58.60 \%)$, those with 5 or 6 streams were $6(20.70 \%)$, those with 1 or 2 were $3(10.30 \%)$, those with 7 or 8 were $2(6.90 \%)$ while those with more than 8 streams were 1(3.40\%). The fact that majority of secondary schools in Nairobi County have between 3 to 6 streams indicated that they require appropriate approach to budgeting propose to ensure adequate utilization of instructional resources.

\section{Number of Teachers in Secondary Schools}

The number of teachers in a schools plays a pivotal role in instructional management from selection of subjects, decision on necessary instructional resources to evaluation of learning outcomes. Findings in Table 4.2 indicates that secondary schools with 21-30 teachers were $14(48.30 \%)$, those with $31-40$ teachers were $7(24.10 \%)$, those with $11-20$ teachers were $5(17.20 \%)$ while those with more than 40 teachers were $3(10.30 \%)$. From these findings it is clear that only $17.20 \%$ (5) secondary schools in Nairobi County have less than 20 teachers. The number of teachers in secondary schools in Nairobi County necessitates decentralize management through empowering departments to enable effective participation of science 
teacher budgeting process. This is in line with Wadesago (2012) who recommended that participatory decision making process should involve all and that this would lead to improved learning outcomes.

\section{Staffing in Different Categories of Schools}

Effective science instructions requires adequate number of teachers in secondary schools (Student-teacher ratio). According to EFA Global Monitoring Report, due to financial constraints, it has not been possible for Kenya to meet international standard as far as studentteacher ratio is concerned (UNESCO, 2015). Analysis of data obtained on the distribution of teachers in this study was presented in Table 4.3.

Table 2: Teachers in Different School Category

\begin{tabular}{lcccccc}
\hline $\begin{array}{l}\text { Number } \\
\text { Teachers }\end{array}$ & of & $\mathbf{1 1 - 2 0}$ & $\mathbf{2 1 - 3 0}$ & $\mathbf{3 1 - 4 0}$ & $\begin{array}{c}\text { More than } \\
\mathbf{4 0}\end{array}$ & $\begin{array}{c}\text { Tota } \\
\mathbf{1}\end{array}$ \\
\hline National & & 0 & 0 & 1 & 1 & 2 \\
County & & 2 & 9 & 2 & 2 & 15 \\
Private & & 5 & 5 & 2 & 0 & 12 \\
Total & $\mathbf{7}$ & $\mathbf{1 4}$ & $\mathbf{5}$ & $\mathbf{3}$ & $\mathbf{2 9}$ \\
\hline
\end{tabular}

From Table 2, one of the two national secondary schools had more than 40 teachers. Another 2 of the 15 county ones also had more than 40 teachers. Among county secondary schools, 2 schools had more than 31-40 teachers. Two private secondary schools had 31-40 teachers. Nine county secondary schools as well as 5 private secondary schools had 21-30 teachers. Finally in 5 private and 2 county secondary schools in Nairobi County there were 11-20 teachers. These findings are an indication that national secondary schools are better staffed while privates once are not adequately staffed. However, the number of teachers could also depend on student enrollment. Otherwise, as already mentioned the larger the staff the more advisable is it for secondary schools to have decentralized management that would encourage participation of science teachers in budgetary allocation decisions for instructional resources.

\section{School Financial Policy Framework}

In this study, science teachers were asked to indicate on a five point scale the extent to which a number of issues correctly describe budgeting process in their school on a five-likert scale, $(1=$ strongly disagree, $2=$ Disagree, $3=$ Uncertain, $4=$ Agree and $5=$ Strongly Disagree).The descriptive statistic presented in tables in this section was interpreted using means to indicate score for budgeting process practices. A mean score of 1 or less implies total disagreement that budgeting process aspects to which it applies is not practiced at all in budgeting for instructional resources by secondary schools in Nairobi County studied. A mean score above 1 but less than 2 indicates disagreement, mean score less than 3 but more than 2 suggests uncertainty, and mean score of above 3 but less than 4 implies secondary schools studied practice the budgeting process aspect and embraces it. Finally a mean score ranging from 4 to 5 indicates that the budgeting process aspect is very prevalent among the respondent secondary schools. In this study policy framework was looked at by considering its existence and influence on budgeting guidelines, budgetary priorities, sources of resources and financial accountability. The results obtained from the responses of science teachers are presented in Table 3 
Table 3: Results on School Financial Management Policy

\begin{tabular}{|c|c|c|c|}
\hline Descriptive Statistics & $\mathbf{N}$ & Mean & Std. Dev \\
\hline $\begin{array}{l}\text { School has a financial policy informing budgeting } \\
\text { process. }\end{array}$ & 83 & 3.82 & .466 \\
\hline $\begin{array}{l}\text { School financial policy have set objectives that inform } \\
\text { budgetary allocations for the instructional resources for } \\
\text { science subjects. }\end{array}$ & 83 & 3.47 & .554 \\
\hline $\begin{array}{l}\text { All expected resources including fees, grants and } \\
\text { subsidies are considered in budgetary allocation for } \\
\text { science instructional resources. }\end{array}$ & 83 & 3.35 & .502 \\
\hline $\begin{array}{l}\text { Management procedures for sourcing science } \\
\text { instructional resources are standardized according to } \\
\text { laid down practices. }\end{array}$ & 83 & 3.41 & .612 \\
\hline $\begin{array}{l}\text { Policy provided guidelines for accountability in sourcing } \\
\text { of instructional resources exists in the school. }\end{array}$ & 83 & 3.57 & .502 \\
\hline
\end{tabular}

\section{Existence of Financial Management Policy in Secondary Schools}

A secondary school financial management policy aims at facilitating learning outcomes in sciences by providing a framework to guide budgetary allocations for instructional resources. According to Kahavizakiriza et al (2015), financial management policy provides secondary schools leadership with a basis that guides instructional management through adequate budgetary allocations. This supportds continuous improvements in science learning through appropriate utilization instructional resources at all level in secondary schools. In this study, science teachers were asked about existence of a financial management policy informing budgeting process in their respective secondary schools. Analysis of science teachers responses according to Table 3 , gave a mean of 3.82 and standard deviation is 0.466 . The mean of 3.82 was an indication that according science teachers' secondary schools in Nairobi County have a financial management policy. Generally, on formulation or review of school financial management policy, science teacher noted that it is the work of the principal and the BOM. During interviews most principals indicated that their schools have financial management policy. As much as it could be true that most schools had financial management policy. This finding could be explained by a possibility of error of social desirability. This echoes Wagithunu et al (2015) assertion that there is lack of professionalism in the management of school finances and principals' attitude towards managing schools resources. Secondly. The responses from science teachers and from principals could be attributed to the fact that Kenyan schools are served with ministerial guidelines on funds management, but individual schools are at liberty to organize and manage their funds depending on the nature of their leadership. However, standard deviation of 0.466 put some doubts to the fact that secondary schools in Nairobi have financial management policy documents. A clear picture came from further analysis as presented in Table 4

Table 4. Science Teachers and Existence of FMP

\begin{tabular}{lcccc}
\hline & Uncertain & Agree & Strongly Agree & Total \\
\hline National & 0 & 5 & 1 & 6 \\
County & 12 & 25 & 4 & 41 \\
Private & 10 & 24 & 2 & 36 \\
Total & $22(26.50 \%)$ & $54(65.10 \%)$ & $7(8.40 \%)$ & 83 \\
\hline
\end{tabular}

Findings in Table 4 indicated that $65.10 \%$ (54) of science teachers in secondary schools in Nairobi County agreed and $8.40 \%$ (7) strongly agreed and $26.50 \%$ (22) were uncertain of their schools having a financial management policy. Uncertainty by $26.50 \%$ (22) of science teachers could be attributed to secondary schools leadership style. This confirmed assertions of 
Motsamai et al (2011) and Robinson et al (2008) that variation in financial leadership approaches exists in secondary schools. This would have a significant influence on science instruction. Further these findings agreed with Lawrence and Orodho (2014) that variation in instructional management is uniquely a factor on school specific financial leadership approach. Table 4, further showed an indication of more likelihood for national schools to have financial management policy because out of 6 science teachers 5 agreed and 1 strongly agreed of its existence in their institutions. For county schools, out of 41 science teachers 12 were uncertain, 25 agreed and 4 strongly agreed that their schools had financial management policy. The trend in county secondary schools was also true in private secondary schools where 10 science teachers were uncertain, 24 agreed and 2 strongly agreed. These variations would influence utilization of instructional resources through budgeting process in secondary schools

\section{Budgeting Guidelines}

Financial management policy provides for economic planning and utilization of school funds for realization of instructional goals. Specifically, school financial management policy guides budgeting process and is a framework for overseeing, directing, conducting, regulating and controlling science instructions. The findings in Table 3 indicates that responses from 83 science teachers gave a mean of 3.47 and a standard deviation of 0.554 . The mean of 3.47 was an indication that respondents agreed that secondary schools in Nairobi County had financial management policy with objectives that inform budgetary allocation for instructional resources for sciences. However, standard deviation of 0.554 was an indication that in as much as financial policy in the sampled secondary schools have objectives that inform budgetary allocation for instructional resources for science subjects, there was a reasonable deviation from the group mean score. Though the study findings indicated general agreement that schools' financial management policies provided budgeting guidelines in allocation for instructional resources, further analysis gave a different picture as presented in Table 5

Table 5: Science Teachers and Budgeting Guidelines

\begin{tabular}{lccccc}
\hline $\begin{array}{l}\text { School } \\
\text { category }\end{array}$ & Disagree & Uncertain & Agree & $\begin{array}{c}\text { Strongly } \\
\text { Agree }\end{array}$ & Total \\
\hline National & 0 & 1 & 4 & 1 & 6 \\
County & 4 & 19 & 14 & 4 & 41 \\
Private & 2 & 19 & 13 & 2 & 36 \\
Total & $6(7.20 \%)$ & $39(47.00 \%)$ & $31(37.30 \%)$ & $7(8.40 \%)$ & 83 \\
\hline
\end{tabular}

Findings in Table 5 showed that 47\% (39) of science teachers were uncertain and 7.20\% (6) disagreed, slightly more than half of those who responded. This was an indication that in about a half of secondary schools in Nairobi County, financial management policy did not have objectives guiding budgetary allocation for science instructional resources. The results also showed an indication that many science teachers could not have been aware of existence of a financial management policy in their institutions. This therefore implies that science teachers in a number of secondary schools in Nairobi were not involved in financial issues in their respective institutions. These findings are in tandem with assertion by Motsamai et al (2011) that many secondary schools leadership do not involve science teachers in decisions leading to budgetary allocation decisions for instructional resources. It can therefore be argued from these findings that as much financial management policies could be influencing budgetary allocation for science instructional resources, leadership approaches in differences secondary schools is another factor. However, as suggested by Asiabaka (2008) governments need to put in place a policy framework on minimum standards for budgetary allocation to improve utilization of instructional resources. This will ensure quality science instruction, vital for 
national development which according to Okumbe (2007) can only be achieved when instructional resources are made available through a policy guided budgetary allocation.

\section{Resourcing Instructional Resources}

Secondary education in Kenya is financed from various sources, depending on categories of schools. According to Otieno and Colclough (2009), public secondary schools are mainly financed by the government out of funds voted by parliament each year and levies paid by parents. Alternatively there are other sources of financing secondary education include income generating projects, contributions or donations by private sources and special grants by government for specific activities. (KIPPRA, 2007). However, increased enrollment in secondary schools requires increased mobilization of resources to supplement government funding and fees paid by parents in budgeting for science instructional resources. Response of science teachers regarding expected financial resources considered in budgetary allocation for science instructional resources according to Table 3 gave a mean of 3.35 and a standard deviation of 0.502 . Mean of 3.35 was an indication that all available resources are considered in budgetary allocations for instructional management in secondary schools in Nairobi County. Standard deviation of 0.502 was an indication that in a number of schools science teachers are not aware of different resources considered in budgetary allocation in instructional management. This needed further analysis of the results as presented in Table 6

Table 6: Science Teachers and Financial Resources

\begin{tabular}{lcccccc}
\hline $\begin{array}{l}\text { School } \\
\text { category }\end{array}$ & $\begin{array}{c}\text { Strongly } \\
\text { Disagree }\end{array}$ & Disagree & Uncertain & Agree & $\begin{array}{c}\text { Strongly } \\
\text { Agree }\end{array}$ & Total \\
\hline National & 0 & 1 & 3 & 2 & 0 & 6 \\
County & 0 & 2 & 17 & 19 & 3 & 41 \\
Private & 1 & 6 & 16 & 13 & 0 & 36 \\
Total & $1(1.20 \%)$ & $9(10.80 \%)$ & $36(43.40 \%)$ & $34(41.00 \%)$ & $3(3.60 \%)$ & 83 \\
\hline
\end{tabular}

Findings in Table 6 indicated that majority of science teacher were uncertain whether other sources of funds were considered when budgetary allocation are done for instructional resources. Specifically $43.4 \%$ (36) of science teachers were uncertain, 41\% (34) agreed, 3.60\% (3) strongly agreed, $10.80 \%$ (9) disagreed and $1.20 \%$ (1) strongly disagreed. The fact that more than half of science teachers were either uncertain or disagreed was an indication of limited involvement of science teachers in financial management issues. Secondly, results in Table 4.12 showed that acknowledging the use of alternative funding sources in budgetary allocation decision for instructional resources vary among science teachers in different categories of secondary schools in Nairobi County. Results in Table 6, further indicated that science teachers in public secondary schools were more certain of alternative funding sources for instructional resources. Specifically 41 science teachers from county schools, 3 strongly agreed, 19 agreed, 17 were uncertain and 2 disagreed. Among 6 science teachers from national schools, 2 agreed, 3 were uncertain and 1 disagreed. From private secondary schools, out of 36 science teachers 13 agreed, 16 were uncertain, 6 disagreed and 1 strongly disagrees. These results suggested that in private secondary schools leadership could be less open with limited involvement of science teachers in financial issues. However, a study conducted by Obunya (2008) indicated that some schools mobilize resources to supplement government funding and fees to boost instructional resources demands than others.

\section{Standardized Budgeting Procedures}

The mandate of the education sector in national development is derived from the Constitution of Kenya (2010). Constitutional provisions are translated into financial management policies to enable institutions and their staff to concentrate their scarce time on instructional priorities. School financial management policy should therefore provide standardized procedures in 
managing institutional resources. According to the analysis of findings tabulated in Table. 4.9, a mean of 3.41 and a standard deviation of 0.512 was obtained. A mean of 3.41 was an indication of availability of standardized procedures in sourcing for science instructional resources though with a great deviation from the mean score. Standard deviation of 0.512 was an indications that as much as science teachers acknowledged existence of management procedures for sourcing science instructional resources are standardized according to laid down practices, there is a considerable variation in their responses. It meant that several secondary schools could not essentially demonstrate value for money and exercising proper controls in managing allocated resources towards realization of instructional goals. To interrogate this deviation further analysis was done and results presented in Table 7

Table 7: Science Teachers and Standardized Budgeting Procedures

\begin{tabular}{lccccc}
\hline $\begin{array}{l}\text { School } \\
\text { category }\end{array}$ & Disagree & Uncertain & Agree & $\begin{array}{c}\text { Strongly } \\
\text { Agree }\end{array}$ & Total \\
\hline National & 1 & 1 & 3 & 1 & 6 \\
County & 2 & 17 & 18 & 4 & 41 \\
Private & 8 & 15 & 12 & 1 & 36 \\
Total & $11(13.20 \%)$ & $33(39.80 \%)$ & $33(39.80 \%)$ & $6(7.20 \%)$ & 83 \\
\hline
\end{tabular}

Findings in Table 7 indicated that out of 83 science teachers, 39.80\% (33) agreed that standardized procedures existed, $7.20 \%$ (6) strongly agreed, 39.80\% (33) and 13.20\% (11) disagreed. The fact that 39.80\% (33) agreed and $7.20 \%$ (6) strongly agreed was an indication that in slightly less than half of secondary schools in Nairobi County had financial management policies providing standardized procedures were available. Having standardized procedures according to Oplatka (2004) was an indication that secondary schools had rules, regulation and guidelines for planning and utilization of instructional management. Further Table 7 provided an analysis of science teachers' responses according to secondary schools categories. These findings revealed existence of standardized procedure in most public institutions as compared to their private counterparts. Specifically, 26 science teachers from public secondary schools out of 47 who responded to the questionnaires agreed compared with the 12 out 36 from private category. This variation could be explained by the findings of Okoth (2003) who asserted that some private secondary school are better managed and are comparable to public secondary schools in terms of linking financial leadership and instructional management.

\section{Financial Accountability}

Accountability activities includes financial accounting and reporting taking into consideration accounting controls, procurement controls, physical controls, performance measurement and internal audit. To enhance accountability, school financial management policy should provide a control mechanisms that would ensure optimal use of available resources for quality instructional results. Science teachers' responses on schools financial management policies provisions on guidelines for accountability in sourcing of instructional resources according to Table 3 gave a mean of 3.57 and standard deviation of 0.502 . Mean of 3.57 was an indication that secondary school financial management policies in Nairobi County had accountability provisions. Meanwhile a standard deviation of 0.502 indicated a considerable variation in their responses. Further analysis through cross-tabulation was used to asses this deviation and results presented in Table 8 
Table 8: Science Teachers and Financial Accountability

\begin{tabular}{lccccc}
\hline School category & Disagree & Uncertain & Agree & $\begin{array}{c}\text { Strongly } \\
\text { Agree }\end{array}$ & $\begin{array}{c}\text { Tota } \\
\text { l }\end{array}$ \\
\hline National & 1 & 2 & 2 & 1 & 6 \\
County & 3 & 17 & 16 & 5 & 41 \\
Private & 0 & 15 & 21 & 0 & 36 \\
Total & $4(4.80 \%)$ & $34(41.00 \%)$ & $39(47.00 \%)$ & $6(7.20 \%)$ & 83 \\
\hline
\end{tabular}

Findings Table 8 showed that $47.00 \%$ (39) of science teachers agreed, $7.20 \%$ (6) strongly agreed, $41.00 \%$ (34) were uncertain and 4.80\% (4) disagreed on existence of accountability provisions in secondary schools in Nairobi County. These results were an indication that slightly more than half of secondary schools in Nairobi County had accountability provision in their financial management policies. However, high number of uncertainty or disagreement suggested that secondary schools could run into the possibility of misappropriation of funds in in some secondary schools in Nairobi County. Lack of accountability measure could lead to misappropriation, fraud, pilfering of cash, theft and improper control of financial records in some secondary schools (Mestry, 2006). It is essential that such secondary schools set up systems of control and accountability to effectively manage instructional process. Further, Table 8 showed that out of 36 science teachers from private secondary schools 21 agreed and 15 were uncertain on the existence of accountability provisions. From county secondary schools, 6 science teachers agreed, 5 strongly agreed, 17 were uncertain and 3 disagreed on existence of accountability provisions. From national secondary schools, 1 science teacher strongly agreed, 2 agreed, 2 were uncertain and 1 disagreed on existence of accountability provisions. This was an indication that private secondary schools were more accountable and this could significantly influence utilization of instructional resources.

\section{CONCLUSION}

Financial leadership and instructional management expectations as far as learning outcomes in science subject is the same in both private and public secondary schools. Section 52, 55 and 61 of Basic Education Act No 142013 demands that secondary schools establish necessary educational and governance structures including maintaining necessary instructional resources. Therefore, whichever the type of school, the need for adequate budgetary allocation have a significance on appropriate utilization of science instructional resources for better learning outcomes. The basis of quality instruction is domesticated within Constitution of Kenya (2010) articles 43.1f, 53.1b and 55a which make education a right and Vision 2030 which underscores the importance of education in ensuring relevant human and social capital for sustainable development. School financial management policy should take care of provisions of these instruments in guiding budgeting process as way toward quality science instructions. This is the first step in ensuring adequate budgetary allocation for instructional resources to be utilized in learning biology, chemistry and physics.

Financial management policy provides secondary schools leadership with a basis that guides instructional management through adequate budgetary allocations to supports continuous improvements in science learning. Findings of this study indicated secondary schools in Nairobi County have a financial management policy. However, formulation and review of the school financial management policy varies in secondary schools irrespective of their category. This is attributed to the fact that Kenyan schools are served with ministerial guidelines on funds management, but individual schools are at liberty to organize and manage their funds according to leadership. This variation in financial leadership styles not only influence certainty of secondary schools having a management policy for managing finances, but would further affect science instructions. Further it automatically influence utilization of instructional resources through budgeting process in secondary schools in Nairobi County. 
Secondary school financial management policy guides budgeting process and is a framework for overseeing, directing, conducting, regulating and controlling in science instructions. Findings of this study indicated that secondary schools in Nairobi County have a financial management policy with objectives that inform budgetary allocation for instructional resources for sciences. However, there was high uncertainty among the science teachers which was attributed to extent of their involvement in budgetary allocation decisions for instructional resources. This is dependent on secondary schools financial leadership approach through it was difficult to pin-point which secondary schools category science teachers were aware of existence of budgetary objectives guiding allocations of instruction resources.

Secondary education in Kenya' is financed from various sources, which include government grants, fees paid by parents, income generating projects, contributions or donations by private sources. However, high requires increased mobilization of resources to supplement government funding and fees paid by parents in budgeting for science instructional resources. Form this study it was established that funds from all sources are considered for budgetary allocations for instructional resources. Adequate funding in secondary schools will positively influence budgetary allocation for science instructional resources and appropriately improve utilization for better learning outcomes. It was also established that use of alternative funding sources in budgetary allocation decision for instructional resources would vary among secondary schools in Nairobi County. Further there was an indication that some schools are well equipped as far as adequacy of instructional resources and this would influence learning outcomes in sciences. Study findings also revealed that science teachers in public secondary schools were more certain of alternative funding sources for instructional resources. This suggested that in private secondary schools leadership could be less open with limited involvement of science teachers in financial issues. Secondary schools principals confirmed that need for school managements to explore other alternative sources of financing budgetary allocations for science instructional resources in order to realize educational goals.

The Constitution of Kenya 2010 sets out the overall guidelines on the management of public resources as provided by various legislations and policy documents. These constitutional provisions are translated into financial management policies to enable institutions and their staff to concentrate their scarce time on instructional priorities. School financial management policy should therefore provide standardized procedures in managing institutional resources. Findings of this study was an indication that there were standardized procedures in sourcing of science instructional resources though with a great deviation from the mean score. However, analysis of results according to secondary schools categories as indicated that more science teachers in public secondary schools acknowledged existence of existence of standardized procedure in financial management than those from private ones..

Secondary school financial management policy should provide a control mechanisms that determines how to use the available resources optimally to produce quality results. These control mechanisms are tenets of Public Finance Management Act 2012 (Republic of Kenya, 2012), other Public Finance legislation enacted pursuant to the provisions of Chapter 12 of the Constitution of Kenya (2010) and the Strategy for Public Finance Management Reforms in Kenya 2013 - 2018. Findings of this study confirmed that Nairobi County secondary school financial management policies had accountability provisions. Having accountability provisions in schools is vital a step towards achieving instructional goals. However, high number of uncertainty or disagreement suggested mismanagement of funds through misappropriation, fraud, pilfering of cash, theft and improper control of financial records in some secondary 
schools. Further there was an indication that private secondary schools were more accountable.

\section{RECOMMENDATIONS}

The recommendations are made both in managerial and policy perspectives plus areas for further research. At managerial level, the recommendations provide guidelines to principals as both financial and instructional managers. At policy level, the recommendations are aimed at bringing to light the need to institute appropriate regulatory mechanisms meant to enhance instructional management in terms of budgetary allocation and utilization. There is need for the government through both the TSC and country directors to ensure that all secondary schools have a financial management policy which conforms to provisions of Constitution of Kenya (2010), Public Procurement and Disposal Act 2005, Basic Education Act 2012, Public Finance Management Act 2012 and other related legal instruments to guide budgetary allocation for instructional resources. Finally, this study recommended that further research should be done on the role science teachers in financial decision making as far as instructional management is concerned. .

\section{References}

Ankomah, Y., Koomson J., Bosu R., \& Oduro G. K. T (2005). Implementing Quality Education in Low-Income Countries (Edqual). University of Cape Coast, Ghana.

Chaudhury, N., Hammer, J., Kremer, M., Muralidharan, K. and RogersSource, F. H. (2006) 'Missing in Action: Teacher and Health Worker Absence in Developing Countries', The Journal of Economic Perspectives

Chetambve and Sakwa (2013)

Chetambve, H. N., \& Sakwa, M. (2013). Effects of Financial Training on Financial Performance of Schools in Kenya: A Survey of Administrators of Secondary Schools in Trans-Nzoia County. International Journal of Academic Research in Business and Social Sciences, 3 (10), 214 - 220.

Clarke, A. (2007) The Handbook of School Management. Cape Town: Kate McCallum.

De Grauwe, Anton and Candy Lugaz with Tiberius Barasa, Pulane J. Lefoka, MathaboTsepa, Samuel Kayabwe and Wilson Asiimwe (2011) Strengthening Local Actors: The Path to Decentralizing Education, Kenya, Uganda, and Lesotho, Paris: IIEP and UNESCO\

Du Preez P, Grobler B, Loock C, Shaba SM 2003. Effective Education Management Series, Module 5: Managing School Finances. Sandown: Heinemann Publishers.

Etindi, K.A. (2000). A Case Study of the Factors that Impede and Affect Effective Inspection and Supervision of Primary Schools in Butere Mumias District, Kenya. Unpublished M.Ed Dissertation, Kenyatta University Glen (2007)

Hammond L. (2007). Educational Leadership: A Bridge to School Reform. A Paper Presented at the Wallace Foundation Conference.

Joubert R, Bray E 2007. Public School Governance in South Africa. Pretoria: Interuniversity Centre for Education Law and Education policy (CELP).

Kahavizakiriza et al (2015)

KIM (2010)

Kipng'etich K \& Ahmed O (2009). Head teachers' Perception of Their Roles in Secondary Schools in Kenya: A Study of Kericho Day Secondary School in Kericho County

KIPPRA, 2007).

Kippra.(2007), Draft Report on "Financing Sources for Achieving MDGs in Kenya: Domestic Resources, Dept and ODA". KIPPRA, Nairobi

Lawrence and Orodho (2014),

Mestry R. (2006) Financial Accountability: The Principal or the school governing body in 
Mngoma S.S.I. (2009) Decentralised financial management in South African schools: An examination of implementation by selected primary and secondary schools in Kwa Ndengezi area in Kwazulu-Natal. University of Kwazulu-Natal: Durban.

Motsamai J M, Lynette J and Corene W (2011) Policy and Practice: Financial Management in Schools in the Mafeteng District of Lesotho Journal of Social Sciences Vol 26 No 2 pp105-116 (2011

Naidoo, Jordan P. (2005) Educational Decentralization and School Governance in South Africa: From Policy to Practice, Paris: International Institute for Education Planning, UNESCO

Nolan A. (2013). Economic and Social Rights, Budgets and the Convention on the Rights of the Child. Intemational journal of Children's Rights 21 \{2013) 248- 277

Obunya, 2008).

Okoth S. 0 2003, Free Primary Education In Public Schools: Implication For Private Primary Schools in Kenya. Unpublished Thesis UON

Okumbe (2007)

Onsomu, 2014).

Oplatka 2004

Otieno and Colclough (2009),

Oyier C. R., Odundo P A, Ganira, K. L \& Wangui K R (2015) Effects of ICT Integration in Management of Private Secondary Schools in Nairobi County, Kenya: Policy Options and Practices. World Journal of Education Vol 5, No.6 2015 URL: http://dx.doi.org/10.5430/wje.v5n6p14

Republic of Kenya (2012): Public Finance Management Act 2012 Government Printer Nairobi

Republic of Kenya (2013a): Basic Education Act 2013. Government Printer Nairobi

Republic of Kenya (2012): Public Finance Management Act 2012

Republic of Kenya (2013b): Public Finance Management Reforms in Kenya 2013 - 2018 Republic of Kenya, 2013a).

Republic of Kenya (2005): Public Procurement and Disposal Act 2005,

Republic of Kenya (20110): The Constitution of Kenya 2010

Robinson et al $(2008$

UNESCO. (2015). Education for All Global Monitoring Report 2015. Paris: UNESCO Unpublished M.Ed dissertation in Educational Management, University of Ilorin

Uya, C. E. (2004). Strategies for promoting good reading habits among junior secondary school students. Literacy Reading in Nigeria.

Wadesango, N. 2012. The Influence of Teachers Participation in Decision-Making on their Occupational Morale. Waltersisulu University. East London, Republic of South Africa.

Wagithunu N M, Muthee J and Thinguri R (2014), A Critical Analysis of School Principals' Competence in Financial Management in Kenya: Accountability in Educational Planning and Management. Journal of Education and Practice, Vol.5, No.25, 2014

Walter, K.E. (2009). Making Good Choices: Sustainable School Improvement. Portland, OR: Northwest Regional 